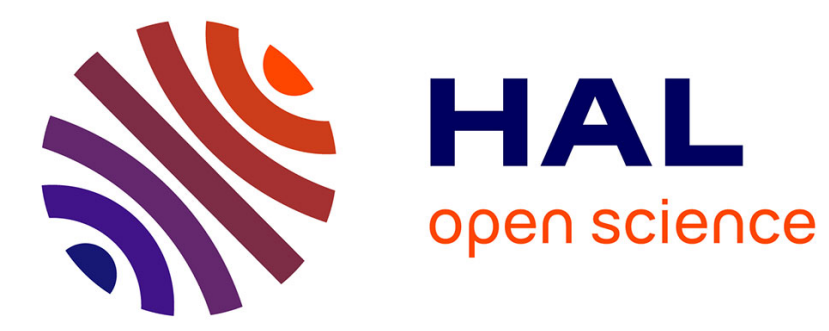

\title{
The crystal structure of the sodium erbium orthovanadate [alpha]-Na3Er(VO4)2
}

Roger Salmon, Claude Parent, Gilles Le Flem, Marcus Vlasse

\section{To cite this version:}

Roger Salmon, Claude Parent, Gilles Le Flem, Marcus Vlasse. The crystal structure of the sodium erbium orthovanadate [alpha]-Na3Er(VO4)2. Acta crystallographica Section B: Structural crystallography and crystal chemistry, 1976, 32 (10), pp.2799-2802. 10.1107/S0567740876008911 . hal-00154491

\section{HAL Id: hal-00154491 \\ https://hal.science/hal-00154491}

Submitted on 13 Jun 2007

HAL is a multi-disciplinary open access archive for the deposit and dissemination of scientific research documents, whether they are published or not. The documents may come from teaching and research institutions in France or abroad, or from public or private research centers.
L'archive ouverte pluridisciplinaire HAL, est destinée au dépôt et à la diffusion de documents scientifiques de niveau recherche, publiés ou non, émanant des établissements d'enseignement et de recherche français ou étrangers, des laboratoires publics ou privés. 
Acta Crystallographica Section B

Structural

Science

ISSN 0108-7681

Editor: Carolyn P. Brock

\section{The crystal structure of the sodium erbium orthovanadate $\alpha-\mathrm{Na}_{3} \operatorname{Er}\left(\mathrm{VO}_{4}\right)_{2}$}

R. Salmon, C. Parent, G. Le Flem and M. Vlasse

Copyright $($ International Union of Crystallography

Author(s) of this paper may load this reprint on their own web site provided that this cover page is retained. Republication of this article or its storage in electronic databases or the like is not permitted without prior permission in writing from the IUCr. 
Acta Cryst. (1976). B32, 2799

\title{
The Crystal Structure of the Sodium Erbium Orthovanadate $\alpha-\mathrm{Na}_{3} \mathrm{Er}\left(\mathrm{VO}_{4}\right)_{2}$
}

\author{
By Roger Salmon, Claude Parent, Gilles le Flem and Marcus Vlasse \\ Laboratoire de Chimie du Solide du CNRS, Université de Bordeaux I, 351 cours de la Libération, \\ 33405 Talence, France
}

(Received 23 March 1976; accepted 24 April 1976)

\begin{abstract}
The structure of the low-temperature variety of $\mathrm{Na}_{3} \mathrm{Er}\left(\mathrm{VO}_{4}\right)_{2}$ has been determined from Patterson and Fourier syntheses and refined by full-matrix least squares with single-crystal diffractometer data to $R=0.035$. The space group is $P 2_{1} / n$ with $a=5.490(5), b=9.739(8), c=7.215(5) \AA, \beta=93.07(5)^{\circ}$, $Z=2$. The structure is a network of isolated tetrahedra in which the $\mathrm{Na}$ and Er atoms are arranged in an ordered way. The structure is described from a topological viewpoint.
\end{abstract}

\section{Introduction}

The X-ray diffraction study of the $\mathrm{Na}_{3} \mathrm{VO}_{4}-\mathrm{LnVO}_{4}$ systems ( $\mathrm{Ln}=\mathrm{Y}, \mathrm{La}, \mathrm{Pr}, \mathrm{Dy}, \mathrm{Ho}, \mathrm{Er}, \mathrm{Tm}, \mathrm{Yb}, \mathrm{Lu})$ has allowed the characterization of a series of compounds of general formula $\mathrm{Na}_{3} \mathrm{Ln}\left(\mathrm{VO}_{4}\right)_{2}$ (Le Flem \& Olazcuaga, 1968; Salmon, Parent, Daoudi \& Le Flem, 1975).

$\mathrm{Na}_{3} \mathrm{La}\left(\mathrm{VO}_{4}\right)_{2}$ and $\mathrm{Na}_{3} \mathrm{Pr}\left(\mathrm{VO}_{4}\right)_{2}$ exist in only one allotropic variety. The determination of the crystal structure of $\mathrm{Na}_{3} \mathrm{La}\left(\mathrm{VO}_{4}\right)_{2}$ has shown that it crystallizes with a $\beta-\mathrm{K}_{2} \mathrm{SO}_{4}$ type ordered structure (Vlasse, Salmon \& Parent, 1976).

A high-temperature X-ray diffraction study shows that the $\mathrm{Na}_{3} \mathrm{Ln}\left(\mathrm{VO}_{4}\right)_{2}$ compounds $(\mathrm{Ln}=\mathrm{Y}, \mathrm{Dy}, \mathrm{Ho}$, $\mathrm{Er}, \mathrm{Tm}, \mathrm{Yb}, \mathrm{Lu}$ ) have three allotropic forms: a lowtemperature $\alpha$ monoclinic variety, a high-temperature $\beta$ hexagonal variety and a $\gamma$ variety, which is derived from the $\mathrm{Na}_{2} \mathrm{CrO}_{4}$ structure and is obtained by rapid quenching of the $\beta$ variety (Salmon, Parent, Daoudi \& Le Flem, 1975).

The structural similarities between $\mathrm{Na}_{3} \mathrm{Y}\left(\mathrm{VO}_{4}\right)_{2}$, $\mathrm{Na}_{3} \mathrm{Er}\left(\mathrm{VO}_{4}\right)_{2}$ and $\mathrm{Na}_{3} \mathrm{Yb}\left(\mathrm{VO}_{4}\right)_{2}$ make possible the synthesis of mixed crystals of formula

$\mathrm{Na}_{3}(\mathrm{Y}, \mathrm{Er}, \mathrm{Yb})\left(\mathrm{VO}_{4}\right)_{2}$ which can convert infrared to visible radiation.

To continue the crystal chemical study of these interesting materials and to understand the allotropic transformations of $\mathrm{Na}_{3} \mathrm{Ln}\left(\mathrm{VO}_{4}\right)_{2}(\mathrm{Ln}=\mathrm{Y}, \mathrm{Dy}, \mathrm{Ho}, \mathrm{Er}$, $\mathrm{Tm}, \mathrm{Yb}, \mathrm{Lu})$, a crystallographic study of the $\alpha-\mathrm{Na}_{3} \mathrm{Er}\left(\mathrm{VO}_{4}\right)_{2}$ phase has been undertaken.

\section{Experimental}

\section{Specimen preparation}

$\alpha-\mathrm{Na}_{3} \mathrm{Er}\left(\mathrm{VO}_{4}\right)_{2}$ was obtained in powder form from a stoichiometric mixture of $\mathrm{Na}_{2} \mathrm{CO}_{3}, \mathrm{Er}_{2} \mathrm{O}_{3}$ and $\mathrm{V}_{2} \mathrm{O}_{5}$ heated first to $600^{\circ} \mathrm{C}$ for $15 \mathrm{~h}$ and then at $700^{\circ} \mathrm{C}$ for $24 \mathrm{~h}$.

Single crystals were prepared from a flux containing $5 \mathrm{~mol}$ of $\mathrm{Na}_{3} \mathrm{VO}_{4}$ and $2 \mathrm{~mol}$ of $\mathrm{Na}_{3} \mathrm{Er}\left(\mathrm{VO}_{4}\right)_{2}$. The mix- ture was kept at $1050^{\circ} \mathrm{C}$ for $15 \mathrm{~h}$ in a Pt crucible, and then cooled to $700^{\circ} \mathrm{C}$ at a rate of $4^{\circ} \mathrm{h}^{-1}$. Small needles were separated from the flux by repeated washing in hot water.

\section{Single-crystal diffraction data}

Inspection of the zero- and upper-layer Weissenberg and precession photographs indicates a monoclinic Laue symmetry $2 / \mathrm{m}$. The systematic extinctions, $h 0 l$ : $h+l=2 n+1$ and $0 k 0: k=2 n+1$, are consistent with the space group $P 2_{1} / n\left[4(e): \pm\left(x y z ; \frac{1}{2}+x, \frac{1}{2}-y, \frac{1}{2}+z\right)\right]$. The cell dimensions obtained and refined from singlecrystal data are $a=5.490(5), b=9.739$ (8), $c=7.215$ (5) $\AA, \beta=93.07(5)^{\circ}$. The cell contains two formula units $\left(d_{x}=3.95(2), d_{c}=3.99 \mathrm{~g} \mathrm{~cm}^{-3}\right)$.

A single crystal of $\alpha-\mathrm{Na}_{3} \mathrm{Er}\left(\mathrm{VO}_{4}\right)_{2}$ in the form of a rectangular prism $0.08 \times 0.06 \times 0.06 \mathrm{~mm}$ was mounted about $\mathbf{b}$. The intensities were collected on an EnrafNonius CD-3 three-circle automatic diffractometer with Mo $K \alpha$ radiation $(\lambda=0.70942 \AA)$, a pyrolytic graphite monochromator (002) and a $4^{\circ}$ take-off angle. A scintillation counter and a $\theta-2 \theta$ multiple scanning technique with a scan rate of $10^{\circ}(2 \theta)$ per min were used. The background was taken at each end of the scan range for a time equal to the actual scan time. Three control reflexions measured for every batch of 50 reflexions showed a random fluctuation of about $4 \% .1985$ independent reflexions were measured to a value of $2 \theta_{\max }=80^{\circ} .1574$ had $I>3 \sigma(I)$, where $\sigma(I)=$ [total counts + backgrounds] ${ }^{1 / 2}$, and were considered to be observed. These intensities were corrected for Lorentz and polarization effects, but not for absorption $\left(\lambda_{\text {Mo K} \alpha}, \mu=160 \mathrm{~cm}^{-1}\right)$.

\section{Determination and refinement of the structure}

A Patterson synthesis was used to determine the positions of the heavy atoms. The two $\mathrm{Na}$ and four $\mathrm{O}$ atoms were located in a difference synthesis at an intermediate stage of the refinement. Full-matrix leastsquares refinement (Busing, Martin \& Levy, 1962) with anisotropic temperature factors reduced $R=\sum|| F_{o} \mid-$ 
Table 1. Atomic coordinates and anisotropic temperature factors for $\alpha-\mathrm{Na}_{3} \mathrm{Er}\left(\mathrm{VO}_{4}\right)_{2}$, with standard deviations in parentheses

The anisotropic temperature factor $T=\exp \left[-10^{-5}\left(h^{2} \beta_{11}+k^{2} \beta_{22}+l^{2} \beta_{33}+2 h k \beta_{12}+2 h l \beta_{13}+2 k l \beta_{23}\right)\right]$.

Er

$\mathrm{Na}(1)$

$\mathrm{Na}(2)$

$\mathrm{O}(1)$

$\mathrm{O}(2)$

$\mathrm{O}(3)$

$\mathrm{O}(4)$

\begin{tabular}{lll}
\multicolumn{1}{c}{$x$} & \multicolumn{1}{c}{$y$} & \multicolumn{1}{c}{$z$} \\
$\frac{1}{2}$ & 0 & 0 \\
$0.0169(2)$ & $0.1825(1)$ & $0.2236(1)$ \\
$\frac{1}{2}$ & 0 & $\frac{1}{2}$ \\
$0.5099(6)$ & $0.3567(3)$ & $0.2091(5)$ \\
$0.0589(8)$ & $0.3577(4)$ & $0.2576(6)$ \\
$0.1404(9)$ & $0.0997(5)$ & $0.4048(7)$ \\
$0.1684(9)$ & $0.1327(5)$ & $0.0328(7)$ \\
$0.7122(8)$ & $0.1361(5)$ & $0.2000(7)$
\end{tabular}

$\begin{array}{ccccrc}\beta_{11} & \beta_{22} & \beta_{33} & \beta_{12} & \beta_{13} & \beta_{23} \\ 431(7) & 142(2) & 327(4) & -5(3) & -8(3) & -7(4) \\ 351(17) & 124(6) & 360(11) & 5(4) & -7(5) & -27(7) \\ 2114(155) & 884(59) & 1289(93) & 863(104) & -1140(99) & -761(76) \\ 1034(78) & 384(26) & 927(54) & 114(39) & 154(51) & -51(33) \\ 954(111) & 145(30) & 458(61) & -57(23) & 89(32) & -53(34) \\ 908(116) & 293(39) & 770(78) & 82(54) & -101(38) & 170(46) \\ 852(111) & 324(38) & 590(69) & 155(55) & 150(69) & -86(43) \\ 467(94) & 217(33) & 744(72) & -88(5) & -22(32)-111(40)\end{array}$

$\left|F_{c}\right|\left|/ \sum\right| F_{o} \mid$ to 0.035 , based on a data-to-parameter ratio of $24: 1$ with 67 independent parameters. A final $\left(F_{o}-\right.$ $F_{c}$ ) synthesis confirmed the proposed solution.

$\sum \omega\left(\left|F_{o}\right|-\left|F_{c}\right|\right)^{2}$ was minimized with $\omega$ taken as unity for all reflexions. An overall scale factor was used with

Table 2. Interatomic distances $(\AA)$ and angles $\left({ }^{\circ}\right)$ for $\alpha-\mathrm{Na}_{3} \mathrm{Er}\left(\mathrm{VO}_{4}\right)_{2}$ with their standard deviations in parentheses

\begin{tabular}{|c|c|c|c|}
\hline $\mathrm{V}-\mathrm{O}(1)$ & $1 \cdot 737(4)$ & $\mathrm{O}(1 b)-\mathrm{Na}(1)-\mathrm{O}(2)$ & $93.9(3)$ \\
\hline $\mathrm{V}-\mathrm{O}(2)$ & $1 \cdot 650(5)$ & $\mathrm{O}(1 b)-\mathrm{Na}(1)-\mathrm{O}(2 d)$ & $86 \cdot 1(3)$ \\
\hline $\mathrm{V}-\mathrm{O}(3)$ & $1 \cdot 716(5)$ & $\mathrm{O}(1 b)-\mathrm{Na}(1)-\mathrm{O}(4)$ & $106.6(3)$ \\
\hline $\mathrm{V}-\mathrm{O}(4 a)$ & $1 \cdot 732(5)$ & $\mathrm{O}(1 b)-\mathrm{Na}(1)-\mathrm{O}(4 d)$ & $73 \cdot 4(3)$ \\
\hline$\langle\mathrm{V}-\mathrm{O}\rangle$ & $1 \cdot 708(5)$ & $\begin{array}{l}\mathrm{O}(2)-\mathrm{Na}(1)-\mathrm{O}(4) \\
\mathrm{O}(2)-\mathrm{Na}(1)-\mathrm{O}(4 d)\end{array}$ & $\begin{array}{l}87 \cdot 4(3) \\
92 \cdot 6(3)\end{array}$ \\
\hline $\mathrm{Er}-\mathrm{O}(1 f)$ & $2 \cdot 268(4)$ & & \\
\hline $\mathrm{Er}-\mathrm{O}(1 c)$ & $2 \cdot 268(4)$ & $\mathrm{O}(1)-\mathrm{V}-\mathrm{O}(2)$ & $108 \cdot 8(3)$ \\
\hline $\mathrm{Er}-\mathrm{O}(3)$ & $2 \cdot 256(5)$ & $\mathrm{O}(1)-\mathrm{V}-\mathrm{O}(3)$ & $108.9(3)$ \\
\hline $\mathrm{Er}-\mathrm{O}(3 h)$ & $2 \cdot 256(5)$ & $\mathrm{O}(1)-\mathrm{V}-\mathrm{O}(4)$ & $112.9(3)$ \\
\hline $\mathrm{Er}-\mathrm{O}(4)$ & $2 \cdot 240(5)$ & $\mathrm{O}(2)-\mathrm{V}-\mathrm{O}(3)$ & $107 \cdot 5(3)$ \\
\hline $\mathrm{Er}-\mathrm{O}(4 h)$ & $2 \cdot 240(5)$ & $O(2)-V-O(4)$ & $107.7(3)$ \\
\hline$\langle\mathrm{Er}-\mathrm{O}\rangle$ & $2 \cdot 255(5)$ & $\mathrm{O}(3)-\mathrm{V}-\mathrm{O}(4)$ & $110 \cdot 7(3)$ \\
\hline $\mathrm{Na}(1)-\mathrm{O}(1 b)$ & $2 \cdot 327(4)$ & $\langle\mathrm{O}-\mathrm{V}-\mathrm{O}\rangle$ & $109 \cdot 4(3)$ \\
\hline $\mathrm{Na}(1)-\mathrm{O}(1 c)$ & $2 \cdot 327(4)$ & $\mathrm{O}(1 f)-\mathrm{Er}-\mathrm{O}(3)$ & $83 \cdot 1(3)$ \\
\hline $\mathrm{Na}(1)-\mathrm{O}(2)$ & $2 \cdot 273(5)$ & $\mathrm{O}(1 f)-\mathrm{Er}-\mathrm{O}(3 h)$ & 96.9 (3) \\
\hline $\mathrm{Na}(1)-\mathrm{O}(2 d)$ & $2.273(5)$ & $\mathrm{O}(1 f)-\mathrm{Er}-\mathrm{O}(4)$ & $92.5(3)$ \\
\hline $\mathrm{Na}(1)-\mathrm{O}(4)$ & $2 \cdot 841(5)$ & $\mathrm{O}(1 c)-\mathrm{Er}-\mathrm{O}(4)$ & $87 \cdot 5(3)$ \\
\hline $\mathrm{Na}(1)-\mathrm{O}(4 d)$ & $2 \cdot 841(5)$ & $\mathrm{O}(3)-\mathrm{Er}-\mathrm{O}(4)$ & $89 \cdot 3(3)$ \\
\hline$(\mathrm{Na}(1)-\mathrm{O}\rangle$ & $2 \cdot 480(5)$ & $\mathrm{O}(3 h)-\mathrm{Er}-\mathrm{O}(4)$ & $90 \cdot 7$ (3) \\
\hline $\mathrm{O}(1)-\mathrm{O}(2)$ & $2 \cdot 755(7)$ & $\mathrm{O}(1)-\mathrm{Na}(2)-\mathrm{O}(2 e)$ & $75 \cdot 2(3)$ \\
\hline$O(1)-O(3)$ & $2 \cdot 810(7)$ & $\mathrm{O}(1)-\mathrm{Na}(2)-\mathrm{O}(2 f)$ & $118 \cdot 3(3)$ \\
\hline $\mathrm{O}(1)-\mathrm{O}(4 a)$ & $2 \cdot 892(6)$ & $\mathrm{O}(1)-\mathrm{Na}(2)-\mathrm{O}(3 b)$ & $99.7(3)$ \\
\hline$O(2)-O(2 i)$ & $2 \cdot 874(7)$ & $\mathrm{O}(1)-\mathrm{Na}(2)-\mathrm{O}(4)$ & $117 \cdot 6(3)$ \\
\hline $\mathrm{O}(2)-\mathrm{O}(3)$ & $2 \cdot 716(7)$ & $\mathrm{O}(1)-\mathrm{Na}(2)-\mathrm{O}(1 g)$ & $165 \cdot 4(3)$ \\
\hline $\mathrm{O}(2)-\mathrm{O}(4 a)$ & $2.732(7)$ & $\mathrm{O}(2 e)-\mathrm{Na}(2)-\mathrm{O}(2 f)$ & $69 \cdot 9$ (3) \\
\hline $\mathrm{O}(3)-\mathrm{O}(4 a)$ & $2 \cdot 838(7)$ & $\mathrm{O}(2 e)-\mathrm{Na}(2)-\mathrm{O}(3 b)$ & $110.5(3)$ \\
\hline$\langle O-O\rangle$ & $2 \cdot 802(7)$ & $\mathrm{O}(2 e)-\mathrm{Na}(2)-\mathrm{O}(4)$ & $158 \cdot 3(3)$ \\
\hline & & $\mathrm{O}(2 e)-\mathrm{Na}(2)-\mathrm{O}(1 g)$ & $109 \cdot 2(3)$ \\
\hline $\mathrm{Na}(2)-\mathrm{O}(1)$ & $2 \cdot 519(5)$ & $\mathrm{O}(2 f)-\mathrm{Na}(2)-\mathrm{O}(3 b)$ & $139 \cdot 6(3)$ \\
\hline $\mathrm{Na}(2)-\mathrm{O}(1 g)$ & $3 \cdot 016(5)$ & $\mathrm{O}(2 f)-\mathrm{Na}(2)-\mathrm{O}(4)$ & $88.4(3)$ \\
\hline $\mathrm{Na}(2)-\mathrm{O}(2 e)$ & $2 \cdot 623(6)$ & $\mathrm{O}(2 f)-\mathrm{Na}(2)-\mathrm{O}(1 g)$ & $76.0(3)$ \\
\hline $\mathrm{Na}(2)-\mathrm{O}(2 i)$ & $2 \cdot 384(6)$ & $\mathrm{O}(3 b)-\mathrm{Na}(2)-\mathrm{O}(4)$ & $85 \cdot 6(3)$ \\
\hline $\mathrm{Na}(2)-\mathrm{O}(3 b)$ & $2 \cdot 450(6)$ & $\mathrm{O}(3 b)-\mathrm{Na}(2)-\mathrm{O}(1 g)$ & $65 \cdot 6(3)$ \\
\hline $\mathrm{Na}(2)-\mathrm{O}(4)$ & $2 \cdot 421(6)$ & $\mathrm{O}(4)-\mathrm{Na}(2)-\mathrm{O}(\mathrm{lg})$ & $63 \cdot 2(3)$ \\
\hline $\mathrm{Na}(2)-\mathrm{O}$ & $2 \cdot 596(5)$ & & \\
\hline
\end{tabular}

Symmetry code
(a) $\quad x-1$,
(b) $\frac{1}{2}+x$,
(c) $\frac{1}{2}-x$,
(e) $\frac{1}{2}-x$
(f) $\frac{1}{2}+x, \quad \frac{1}{2}-y, \quad z-\frac{1}{2}$
$\begin{array}{llr}\text { (g) } & 1+x, & y, \quad z \\ \text { (h) } 1-x, & \bar{y}, 1-z\end{array}$
(i) $\quad \bar{x}, \quad \bar{y}, 1-z$

a final value of $3.68\left(F_{o}=k F_{c}\right)$. The form factors for $\mathrm{Er}^{3+}, \mathrm{Na}^{+}, \mathrm{V}^{5+}$ and $\mathrm{O}^{2-}$ were taken from McMaster, Kerr del Grande, Mallet \& Hubbel (1969), with real and imaginary anomalous dispersion terms given by Cromer (1965).

The final atomic and thermal parameters are given in Table 1. Table 2 contains the interatomic distances and angles.

A table giving the calculated and observed structure amplitudes may be obtained on request from M.V.*

\section{Results and discussion}

A projection of the structure on (001) is given in Fig. 1. By comparison with the structure of $\mathrm{Na}_{2} \mathrm{CrO}_{4}$ shown in Fig. 2, which also seems to be the arrangement adopted by the metastable $\gamma$ phase, the structure of $\alpha-\mathrm{Na}_{3} \mathrm{Er}\left(\mathrm{VO}_{4}\right)_{2}$ can be described as an ordered $\mathrm{Na}_{2} \mathrm{CrO}_{4}$ structure with $\mathrm{Na}$ and $\mathrm{Er}$ occupying, in an

* This table has also been deposited with the British Library Lending Division as Supplementary Publication No. SUP $31829(7 \mathrm{pp}$.). Copies may be obtained through The Executive Secretary, International Union of Crystallography, 13 White Friars, Chester $\mathrm{CH} 1 \mathrm{1NZ}$, England.

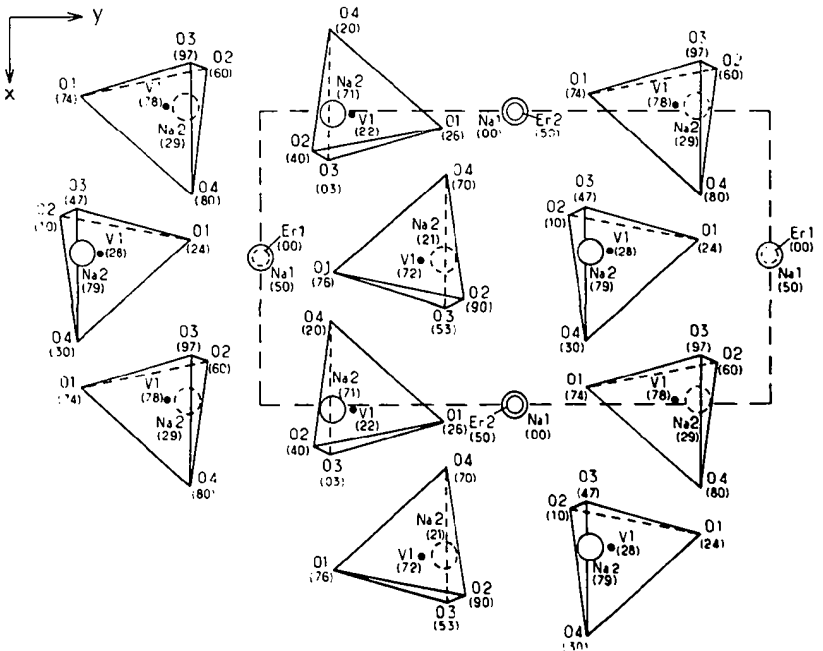

Fig. 1. Projection of the $\alpha-\mathrm{Na}_{3} \mathrm{Er}\left(\mathrm{VO}_{4}\right)_{2}$ structure on the (001) plane. 
ordered way, one of the $\mathrm{Na}$ sites of the $\mathrm{Na}_{2} \mathrm{CrO}_{4}$ lattice. This relationship between $\alpha-\mathrm{Na}_{3} \mathrm{Er}\left(\mathrm{VO}_{4}\right)_{2}$ and $\mathrm{Na}_{2} \mathrm{CrO}_{4}(a=5 \cdot 861, b=9 \cdot 259, c=7 \cdot 138 \AA)$ can be easily established, but a more generalized approach can be more valuable in the description of an

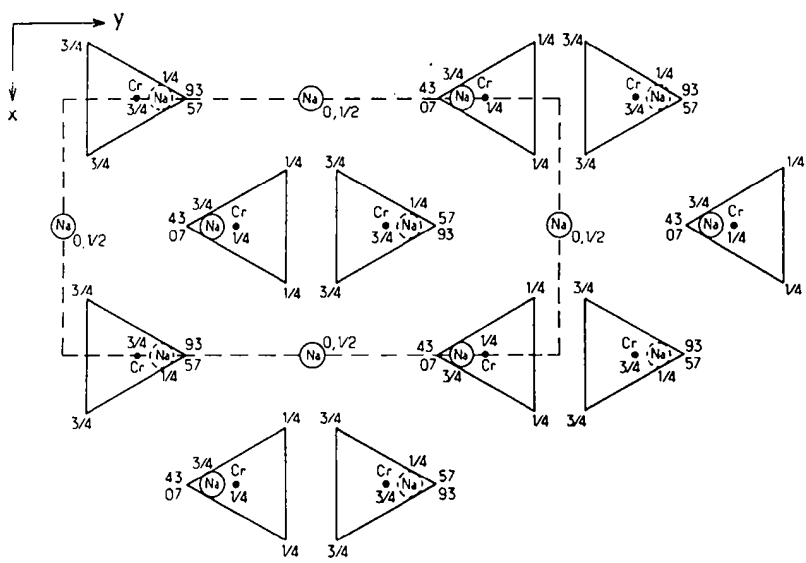

Fig. 2. Projection of the orthorhombic $\mathrm{Na}_{2} \mathrm{CrO}_{4}$ structure on the (001) plane.

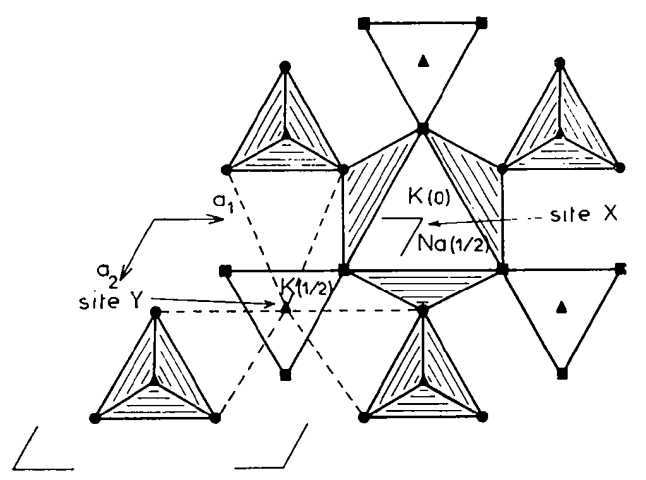

Fig. 3. The glaserite structure shown as a polyhedral diagram. Oxygen atoms having the same symbol are on the same level.

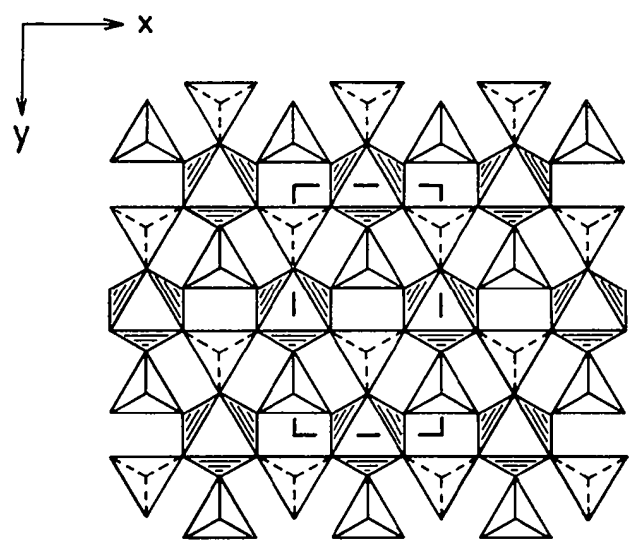

Fig. 4. Condensation of pinwheels corresponding to an idealized sheet of the $\alpha-\mathrm{Na}_{3} \operatorname{Er}\left(\mathrm{VO}_{4}\right)_{2}$ structure. The actual cell is outlined.
$\mathrm{A}_{x} \mathrm{~B}_{y}\left(\mathrm{TO}_{4}\right)_{(x+y) / 2}$ structure. The fact that most of the sulphate, orthosilicate and orthovanadate compounds have structures made up of isolated tetrahedra linked only by cations, as well as pseudo-hexagonal symmetry suggests a more topological approach (Moore \& Araki, 1972; Moore, 1973).

Glaserite $\mathrm{K}_{3} \mathrm{Na}\left(\mathrm{SO}_{4}\right)_{2}$ and the structurally similar aphtitalite $\mathrm{K}_{2} \mathrm{Na}_{2}\left(\mathrm{SO}_{4}\right)_{2}$ have a simple atomic arrangement whose hexagonal geometry defines the substructure observed in other compounds of this type such as $\mathrm{Ca}_{3} \mathrm{Mg}\left(\mathrm{SiO}_{4}\right)_{2}, \alpha-\mathrm{Ca}_{2} \mathrm{SiO}_{4}, \quad \beta-\mathrm{Ca}_{2} \mathrm{SiO}_{4}$ and $\beta-\mathrm{K}_{2} \mathrm{SO}_{4}$. This structure can thus be used as an ideal model in the establishment of structural interrelationships among these phases.

The structure of glaserite is shown in Fig. 3. Two large cationic sites appear in this structure. In a large ideally twelve-coordinated polyhedron (X site) six $\mathrm{O}$ atoms make up a trigonal antiprism; six additional meridional anions constitute a hexagonal ring around this antiprism with $\overline{3} m$ symmetry. The trigonal antiprism found inside the twelve-coordinated polyhedron is in itself an octahedral site. The arrangement of the tetrahedra around this octahedron defines a 'pinwheel' where the apical $\mathrm{O}$ atoms point either up or down. A second large cation polyhedron ( $\mathrm{Y}$ site) is ideally tencoordinated with $3 m$ symmetry; again, six anions are found on the vertices of a meridional hexagon, three above share the tetrahedral base and one below a tetrahedral apex.

Condensation of the 'pinwheels' can lead to a hexagonal close-packed sheet shown in Fig. 4. The comparison of this geometrically idealized structure with the actual structure shown in Fig. 1 reveals their close relationship and corroborates the pseudo-hexagonal character of $\alpha-\mathrm{Na}_{3} \mathrm{Er}\left(\mathrm{VO}_{4}\right)_{2}$. Furthermore, the hexagonal parameters of the high-temperature $\beta$ phase of $\mathrm{Na}_{3} \mathrm{Er}\left(\mathrm{VO}_{4}\right)_{2}$ are $a=5 \cdot 64, c=7 \cdot 46 \AA$, while for glaserite they are $a=5.65, c=7 \cdot 29 \AA$. This leads to the conclusion that $\beta-\mathrm{Na}_{3} \mathrm{Er}\left(\mathrm{VO}_{4}\right)_{2}$ has indeed a glaserite-type structure, while $\alpha-\mathrm{Na}_{3} \mathrm{Er}\left(\mathrm{VO}_{4}\right)_{2}$ is a distorted variation of this glaserite structure and can be derived from a corresponding condensation of idealized 'pinwheels'.

Ideally in this structure four different types of polyhedra can be expected: a tetrahedron $\mathrm{TO}_{4}$; a twelvecoordinated polyhedron $\mathrm{X}^{(12-p)}$ with $p=0$ and an octahedron $\mathrm{M}^{[6]}\left[\mathrm{X}^{(12-p)}\right.$ with $\left.p=6\right]$, both having a common centre (Figs. 3 and 4), and finally a ten-coordinated polyhedron $\mathrm{Y}^{[10]}$ with its centre above or below the tetrahedra (Figs. 3 and 4). Actual structural distortion, due to the need for these sites to accommodate cations of different size and charge, leads to lower coordination numbers as is observed in most of these compounds.

In $\alpha-\mathrm{Na}_{3} \mathrm{Er}\left(\mathrm{VO}_{4}\right)_{2}$ three of the above sites are occupied, but with lower coordination for $\mathrm{Y}$. We thus have a network of isolated vanadate tetrahedra forming the skeleton of this structure. Er and $\mathrm{Na}(1)$ occupy the central $M$ octahedra with coordination six while $\mathrm{Na}(2)$ are in the $\mathrm{Y}$ sites also with six-coordination. The 
actual formula can be written as $\mathrm{Y}_{2}{ }^{[6]} \mathrm{M}_{2}{ }^{[6]}\left[\mathrm{TO}_{4}\right]_{2}$ as compared to the geometrical ideal of

$\mathrm{X}^{[12]} \mathrm{Y}_{2}{ }^{[10]} \mathrm{M}^{[6]}\left[\mathrm{TO}_{4}\right]_{2}$.

The occupation of the different sites by the various atoms is in accordance with the observations of Moore (1973) for a number of similar compounds. When two cations of different charges are present, the lower charged ion will preferentially occupy the $\mathrm{Y}$ polyhedron $\left(\mathrm{Er}^{3+}\right.$ in $\mathrm{M}^{[6]}, \mathrm{Na}^{+}$in $\left.\mathrm{Y}\right)$. A similar observation was made for $\mathrm{Na}_{3} \mathrm{La}\left(\mathrm{VO}_{4}\right)_{2}$ (Vlasse, Salmon \& Parent, 1976).

The average $\mathrm{V}-\mathrm{O}$ distance in the tetrahedron, 1.708 $\AA$, is within the range reported by Robertson \& Kostiner (1972) (1.660 to $1.806 \AA)$ and by Gopal \& Calvo (1973) $(\langle\mathrm{V}-\mathrm{O}\rangle=1.691$ to $1.701 \AA)$ as well as those found in $\mathrm{Na}_{3} \mathrm{La}\left(\mathrm{VO}_{4}\right)_{2}(\langle\mathrm{~V}-\mathrm{O}\rangle=1.673$ to 1.726 $\AA)$. The average $\mathrm{Na}-\mathrm{O}$ distances fall into two classes: a short distance for $\mathrm{Na}(1), 2 \cdot 480$, and a long distance for $\mathrm{Na}(2), 2.569 \AA$. This difference can be explained by the presence of $\mathrm{Na}$ in two different sites. $\mathrm{Na}(1)$ is found in the $M$ site with very little cation-cation repulsion, while $\mathrm{Na}(2)$ occupies the $\mathrm{Y}$ site where there exists severe cation-cation repulsion between this polyhedron and the highly charged tetrahedron with which it shares a face. In this latter site we can expect longer bonds.

The Er-O average distance of 2.255 is comparable to that found by Baglio \& Sovers (1971) $2 \cdot 270 \AA$ for $\mathrm{ErVO}_{4}$.

All $\mathrm{O}-\mathrm{O}$ distances are normal with an average of $2 \cdot 802 \AA$. The average O-V-O angle of $109 \cdot 4^{\circ}$ is also normal. For $\mathrm{Na}_{3} \mathrm{La}\left(\mathrm{VO}_{4}\right)_{2} \quad\langle\mathrm{O}-\mathrm{O}\rangle=2.800 \AA$ and $\langle\mathrm{O}-\mathrm{V}-\mathrm{O}\rangle=109 \cdot 4^{\circ}$.

In conclusion, in structures which are made up of isolated $\mathrm{TX}_{4}$ tetrahedra we observe that these tetrahedra can arrange themselves in a variety of ways by simply rotating around their centres and condensing themselves in 'pinwheels' in such a way that they can accommodate in their network a number of different cations with different coordinations. This explains the fact that $\mathrm{Na}_{3} \mathrm{Er}\left(\mathrm{VO}_{4}\right)_{2}$ can exist in several allotropic modifications, all closely related to the glaserite structure. The $\alpha$ form corresponds to a distortion of the glaserite structure and to an ordered distribution of the $\mathrm{Na}$ and $\mathrm{Er}$ atoms in the $\mathrm{X}$ sites.

The transformation $\alpha \rightarrow \beta$ is characterized by a reorientation of the tetrahedra as well as a disordering of the $\mathrm{Na}$ and $\mathrm{Er}$ atoms. A rapid quenching of the $\beta$ phase gives rise to the $\gamma$ variety where $\mathrm{Na}$ and $\mathrm{Er}$ are also disordered. The fact that the metastable $\gamma$ phase cannot be obtained directly from the low-temperature $\alpha$ phase can also be explained by the large $\mathrm{X}$ site in which $\mathrm{Na}$ and $\mathrm{Er}$ can be found, with very little cationcation repulsion, and where an ordered arrangement is energetically much more favourable.

\section{References}

Baglio, J. A. \& Sovers, O. J. (1971). J. Solid State Chem. $3,458-465$.

Busing, W. R., Martin, K. O. \& LeVy, H. A. (1962). ORFLS. Oak Ridge National Laboratory Report ORNLTM-305.

Cromer, D. T. (1965). Acta Cryst. 18, 17-23.

Gopal, R. \& Calvo, C. (1973). Z. Kristallogr. 137, 67-85.

Le Flem, G. \& Olazcuaga, R. (1968). Bull. Soc. Chim. Fr. 7, 2769-2780

McMaster, W. H., Kerr del Grande, N., Mallet, J. H. \& Hubbel, J. H. (1969). Compilation of X-ray Cross Sections. Natl. Bur. Stand. UCRL-50174, Sec. II, Rev. 1. Moore, P. B. (1973). Amer. Min. 58, 32-42.

Moore, P. B. \& Araki, T. (1972). Amer. Min. 57, 13551374.

Robertson, B. \& Kostiner, E. (1972). J. Solid State Chem. 4, 29-37.

Salmon, R., Parent, C., Daoudi, A., \& le Flem G. (1975). Rev. Chim. Minér. 12, 448-453.

Vlasse, M., Salmon, R. \& Parent, C. (1976). Inorg. Chem. To be published. 